\title{
DỨBin
}

Technological University Dublin ARROW@TU Dublin

\section{Bringing It All Together Through Group Learning}

Shannon Chance

Technological University Dublin, shannon.chance@tudublin.ie

Follow this and additional works at: https://arrow.tudublin.ie/engscheleart2

Part of the Architecture Commons, and the Education Commons

\section{Recommended Citation}

Chance, S. (2014) Bringing It All Together Through Group Learning, New Directions for Higher Education, vol, 2014, issue, 165, pages 107-119, Spring 2014 Article first published online : 27 MAR 2014, DOI:

$10.1002 /$ he. 20088

This Article is brought to you for free and open access by the School of Electrical and Electronic Engineering at ARROW@TU Dublin. It has been accepted for inclusion in Articles by an authorized administrator of ARROW@TU Dublin. For more information, please contact arrow.admin@tudublin.ie, aisling.coyne@tudublin.ie, gerard.connolly@tudublin.ie.

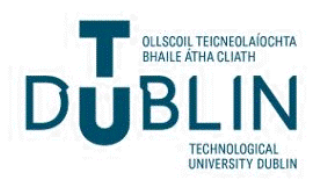


Chapter 10

Interpersonal and trans-disciplinary collaboration can facilitate and amplify the benefits of learning. Drawing from ideas presented throughout this volume, this culminating chapter describes ways to enhance collaborative learning within and among various stakeholder groups.

Bringing it all Together Through Group Learning

Shannon M. Chance

This volume has identified numerous ways to help postsecondary stakeholders learn more effectively. Drawing from existing literature related to "learning," each author has examined ways to push human knowledge forward by implementing innovative theories and pedagogical practices. This final chapter provides both a summary and a launching point for thinking about learning more broadly.

In doing so this chapter: 1) identifies issues common to a variety of stakeholder groups, 2) discusses benefits of collaborative "group learning," 3) provides examples, and 4) presents two new models for fostering learning by promoting collaboration. The new models, generated through a phenomenological study of faculty collaboration that occurred at the Dublin Institute of Technology (DIT) in Ireland, may be useful in other educational environment where greater knowledge sharing is desired, be it among individuals, across programs, or at the institutional/organizational level (Chance, Duffy, \& Bowe, under review). The models are tools for organizational learning of the sort recommended by Moore and Mendez (2014) because they adopt a systems perspective, conceptualize stakeholders as a "community of learners" (Kezar, 2005a, p. 10), and suggest processes "for acquiring information, interpreting data, developing knowledge, and sustaining learning" (Kezar, 2005b, p. 13) across the institution. 
The models build on the work of a small group of electrical engineering lecturers who sought to facilitate and support students' collaborative learning. They succeeded in fostering change in their classrooms, but they also influenced change program-wide. Today, they stand as precedent for others throughout their college, and are encouraged and supported in leading change by college administrators. One major goal of this chapter is to show how the DIT model can help facilitate wide-scale integration of learning and foster transformative change.

The chapter helps address gaps in performance at the institutional/organizational level. Typical deficits in learning at this level include: failure to learn from experience (Kolb, 1984, 1998; Presley \& Leslie, 1999; Rowley, Lujan, \& Dolence, 1997); failure to pool knowledge across disciplines, departments, and administrative units (Barber, 2014; Lauer, 2006); and failure to monitor plans and tweak performance (Holcomb, 2001; Wilson, 1997). As evidenced in the chapters of this volume, a lack of support for making connections and integrating topics hinders learning at all levels.

This chapter showcases how campus members can work together in a selfdirected manner to foster continual learning and continually improved performance. By sharing ideas about learning that work within discrete stakeholder groups and applying them more broadly (i.e., across/among groups), we can connect learning across our institutions.

\section{Core Questions and Best Practices}

At the core of this volume lie questions like: How can leaders use methods that are known to facilitate transformational learning at the level of the individual and apply them to help groups learn more effectively--be these faculty groups or the organization at large? How can institutional leaders amplify positive effects that accrue from using innovative approaches to learning by "scaling them up" and applying them in more ways? To begin 
addressing such questions, let's review major points about learning discussed elsewhere in this book, looking at each major stakeholder group individually and then assessing commonalities.

Whereas postsecondary institutions have traditionally focused on learning at the level of the student (in classrooms) and knowledge generation at the level of the faculty (through research and publication), there is a pressing need to do more to create and apply knowledge in service to society (Kerr, 1995), to learn from experience (Holcomb, 2001; Kolb, 1984, 1998), and to harness new techniques in order to perform more effectively as large-scale organizations (Birnbaum, 1988; Rowley et al., 1997).

This volume suggests many avenues for advancing knowledge by connecting and combining innovative approaches and by addressing gaps through best practices. Higher education organizations often fail to see opportunities for applying learning strategies at multiple scales and thus fail to amplify the benefits. The following sections identify ways to take what works at smaller scales (such as the level of the student and classroom) and apply similar techniques at larger scales (across the faculty and institution, for instance) in order to facilitate organizational learning.

student Learning. In this volume, we've seen that immersive, experiential, and high-engagement activities can facilitate deep learning among students (Wawrzynski \& Baldwin, 2014). Such activities encourage students to connect and integrate what they learn from one setting to the next (Barber, 2014). Innovative approaches--such as those involving civic engagement (Moore \& Mendez, 2014) and technology-assisted, "blended" learning (VanDerLinden, 2014)--can help educators reach more students more effectively. They also can help address differences in students' learning styles (Kolb, 1984, 1998) and extend the benefits of learning beyond the walls of the traditional classroom (Kerr, 1995). This alone can have exponential benefits. 
For instance, Christensen, Horn, and Johnson (2011) explain, up to now textbooks have been written by people who adopted/fit/mastered the dominant learning style used by the particular discipline. Students successful in this hegemonic mode of thinking are encouraged to enter the given field and ultimately replicate similar modes of teaching and learning. This pattern galvanizes the group, but also limits the breadth of perspectives held. Challenging the status quo promotes learning (Christensen et al., 2011). Using technology to adjust delivery, in order to convey content more effectively to a wider array of learners, can strengthen human capacity to address pressing challenges. New technologies also offer new ways to help individuals, organizational units, and institutions integrate learning that is happening in discrete areas (by blending and connecting them, for instance).

In addition, innovative strategies like those discussed in this book can help institutions explain and justify their existence. The tactics can help higher education address public demands for accountability, for moreclearly articulated learning outcomes, and for higher graduation rates. All of these demands equate to ensuring higher return on investment (Leslie, 2014). "Scaling up" effective innovations can help society get more value from its expenditures. Promising innovations include tools to help various stakeholder groups integrate what they learn into wider and more diverse settings.

For students, learning-rich environments that provide fodder for "connection, application, and synthesis" (Barber, 2014) of new knowledge involve: classroom learning, co-curricular activities, internships, service learning/civic engagement projects (Moore \& Mendez, 2014), blended learning (VanDerLinden, 2014), and other immersive experiences (Wawrzynski \& Baldwin, 2014). Today, educators seek to make classrooms into immersive, high-impact environments by using techniques such as experiential learning and group- 
based discovery. These are the same characteristics undergirding cocurricular activities that make them so effective in fostering student development.

Student Learning Groups. Scholars around the globe have shown group learning to be an effective way to foster students' development (Xiangyun, de Graaff, \& Kolmos, 2009; Yadav, Subedi, Lundeberg, \& Bunting, 2011). Such techniques are associated with descriptors like: student-centered, groupbased, enquiry-driven, project-based, and/or problem-based learning. These pedagogical strategies encourage critical thinking and knowledge sharing. They also promote knowledge generation. Educators can use these pedagogies to help students integrate what they learn in various subjects and what they experience thorough many types of activities (Barber, 2014). All of these techniques have been shown to facilitate development of the orthogonal skills described by Leslie (2014). An example of an orthogonal approach in practice occurs for engineering students at DIT, where target skills include: selfdirected learning (SDL), creativity, critical thinking, information literacy, and ethics. In this program, the development of group skills is primary. It serves as a foundation for the development of all other disciplinary and nondisciplinary (e.g., personal) knowledge and skills. As is typical in Europe, students in this program do not take general education courses. Their technical courses must provide the general knowledge and skills necessary for them to succeed in their chosen profession and in life. Over time, direction from the teacher decreases, as students develop aptitude in guiding their own leaning. As this happens, instructors' attention shifts toward helping students improve the quality of the products produced. Objectives, instructional methods, and assessment are aligned. They emphasize process in the early years and product later on.

One increasingly common method for structuring group-based learning among students is called Problem-Based Learning (PBL). This hands-on 
approach, derrived from medical education, places the individual's learning at the fore. Teachers serve as tutors or facilitators; they provide a framework around which students can construct new knowledege.

As codified by Barrows (1994), Problem-Based Learning occurs in small groups (often 6-10 people). A problem--typically a fuzzy, ill-defined, and open-ended one--serves as the vehicle for learning. A teacher or facilitator helps guide the group, primarily serving as a tutor. This person unobtrusively advises the group with regard to learning and decision-making processes so that participants become increasingly effective in directing their own learning processes. The focus of the process is for group members to be the drivers of their own learning.

Faculty Learning. Now, let's shift from considering self-directed learning at the student level to thinking about how it applies to faculty members and organizations. In doing so, we will see that learning theories are highly transferable from one stakeholder group to another. Later we will see that by combining and cross-referencing the learning that occurs within stakeholder groups, we can foster deep, transformational learning at and across various levels. Leaders can encourage this to happen by putting structures in place that facilitate integration. In this way, leaders can serve to pollinate ideas and germinate innovations that blossom up around them.

One type of immersive experience that has power to elicit deep learning for faculty and students alike is study abroad. International experiences can be just as important to faculty learning (Eddy, 2014) as they are for student learning (Lewis \& Niesenbaum, 2005; NAFSA, 2003, 2006). Immersion and active engagement are integral to learning. Reflection can extend the benefits of participating in such programs (Astin, 1999). Prompting travelers to reflect on their experiences (as Eddy did) helps generate more knowledge than the experience alone would (sans reflection). Similarly, 
VanDerLinden (2014) encourages institutional leaders to engage in this type of "critical self-reflection" (p. \# TBD) about organizational learning.

A big take-away from this book is that traditional ways of teaching must be supplemented by new methods of learning and sharing knowledge. We can't rely solely on time-tested pedagogies like study abroad. Getting the most value for every dollar is particularly important in today's budgetary climate (Leslie, 2014). With less money available for faculty development programs, it becomes increasingly important to provide fun, enticing, effective, low-cost ways to enrich faculty members' experiences and facilitate continual learning (Zakrajsek, 2014). Despite (or perhaps because of) the lack of funds for travel and other highly visible professional development programs, much of the onus for continued learning now falls on the individual faculty member. Zakrajsek challenges individual educators to take initiative, identify good sources of knowledge, and engage with others around campus. Taping into the wealth of faculty and staff expertise can foster engagement and provide a ready sense of connection and fulfillment. It can help faculty integrate their own learning, too (Barber, 2014).

Such action requires extra effort, but moving out of one's comfort zone is key to positive growth and development (Sanford, 1962). Facing unfamiliar situations prompts learning. Finding new environments for learning outside one's box is an underlying theme of Eddy's (2014) chapter, which describes how the move to another country can disrupt one's status quo and spark learning. International study programs, while costly, yield untold benefits for the faculty and students fortunate enough to participate (and for society as a whole, according to NAFSA, 2003, 2006). The effect of such programs can be amplified by including requirements for civic engagement (Moore \& Mendez, 2014) as the Fulbright program does (Eddy, 2014). A primary benefit of such programs is development of the orthogonal skills (Leslie, 2014). 
Faculty Learning Groups. Groups of faculty and administrators can learn to self-direct their own leaning. This process can enhace their capacity to generate knowledege, improve performance, and benefit from their own experiences. They can use the constructivist PBL approach defined by Barrows (1994), as happened at DIT. There, an adminstrator who was experienced with PBL guided lecturers through a process of self-directed learning. The faculty-learning group identified its core "problem" as finding ways to facilitate group work among students and to assess students fairly.

Groups as Generators for Organizational Learning. In the US, a number of faculty groups have identified environmental sustainability as a core problem for investigation. Environmental sustainability is pressing, openended issue where neither "the problem" nor "the solution" are readily apparent. Northern Arizona University (Chase \& Rowland, 2014), Oberlin College (2007), and Harvard University (Sharp, 2009) provide vibrant examples of environmental learning that has occurred across stakeholder groups.

Through the Ponderosa Project at Northern Arizona University (NAU) faculty, staff, and students worked together to generate new systems, behaviors, and approaches to achieving environmental sustainability (Chase \& Rowland, 2014). This particular university also provides the context for VanDerLinden's (2014) discussion of blended learning. It appears that NAU consistently uses emerging challenges and technologies to promote active engagement and multi-level learning.

Likewise, events at Oberlin college reflect increased learning across stakeholder groups. Starting in 1992, David Orr began working with student groups to investigate environmental problems related to building design. Serving as a facilitator, he and his students followed a process similar to the one outlined by Barrows (1994). They identified opportunities, needs, where get information, and how to apply it. They worked with architectural consultants to program a new building for their campus--an environmental 
studies center--that was not only built, but also came to serve as a precedent for the design of thousands more buildings around the world. The College has started to create new learning loops that draw from and extend what the student-faculty learning groups discovered/developed/generated. Likewise, Harvard University is creating knowledge about sustainable construction in ways that involve multiple stakeholder groups and improve their buildings' performance (President and Fellows of Harvard College, 2009 , 2010). The university is taking a systems-thinking perspective to engage various groups and to understand better the intersections of learning among stakeholders (Sharp, 2009).

NAU, Oberlin, and Harvard illustrate that learning that occurs among faculty and students has the potential to informal larger systems and address pressing social concerns. Institutional leaders are charged with ensuring that happens.

Learning among Leaders. On most campuses, group learning is not yet being tapped to its full potential by faculty and administrators. Nevertheless, these leaders are the stakeholders who can most affect knowledge-generation at the organizational level, where new methods of learning from experience are highly desirable (Bornstein, 2003; Neumann \& Bolitzer, 2014). Authors included in this volume have discussed the importance of organizational learning (Amey, 2014; Moore \& Mendez, 2014; VanDerLinden, 2014; Wawrzynski \& Baldwin, 2014). Their texts provide keys to helping postsecondary institutions learn more effectively. They can help us understand emerging techniques to address existing deficits. Their ideas can help leaders seize opportunities for growth and productivity. Many of the techniques for organizational learning discussed in this volume were initially developed to facilitate learning by students and faculty. Moore and Mendez (2014) and VanDerLinden (2014) suggest ways to 
harness strategies that have worked at the level of the student/classroom and use them to facilitate organizational learning. One particularly valuable and highly transferrable approach is group-driven Problem-Based Learning.

Like students, faculty and administrative leaders are learners. Faculty members also are decision-makers who can, and should, put in place the structures needed to ensure high-impact learning across the domains for students. Administrative leaders must facilitate this work. Moreover, leaders are charged to create structures that facilitate high-impact learning across the domains for faculty as well as for students. In other words, leaders must create opportunities for faculty learning. In this regard, Neumann and Blitzer's (2014) chapter highlights what leaders should be doing and what they need to know to get it done. "Leaders are usually better positioned," they say "to see, and to explore group-level learning than are other organizational members" (p. \# TBD) .

\section{Learning from Groups at DIT}

DIT takes learning so seriously that the institution employs a "head of learning development" for each college, who works with his/her dean to facilitate multi-dimensional, multi-loop learning. Below, I provide two models to illustrate how muilt-level learning unfolded at DIT. These models can help leaders visualize ways to build momentum within and between various constituent groups in order to prompt deep, transformational learning.

A Model for Multi-Level Learning. DIT showcases a model of multi-loop learning. Here, group discovery served as the primary driver of transformational learning among individuals and the overall organization. At DIT today, more and more lecturers are implementing innovative PBL pedagogies. Even faculty who were initially skeptical about the approach or resistant to change are seeing benefits and altering their behaviors. The institution provides resources to facilitate hands-on problem-based learning by individuals and groups. Today, efforts are underway to scale up, sustain, 
and help direct transformational learning. First, let's look at the core mechanism driving learning/change, in this case the faculty-learning group, shown in the center of Figure 10.1, and then discuss how the system engaged more individuals (shown moving across the diagram from left to right) and began working to learn from members' experiences at the organizational level (shown on the upper right).

[ [ Insert Figure 10.1 About Here] ]

Group Learning. At DIT, one group of faculty so valued the development of students' general, non-disciplinary skills that they met formally throughout the 2009-2010 school year to discuss how to use student learning groups to facilitate orthogonal development of such skills. Their discussions focused on ways to facilitate group learning, provide effective feedback to students, and assess (in a fair way) students working in groups. They developed ideas, tested the ideas in various classroom and laboratory settings, and met to share/reflect upon/refine the results. A study of the faculty-learning group identified four key drivers that were effectively aligned to facilitate movement in the desired direction (Chance et al., under review). Primary drivers were: (1) individuals working together in groups to learn and change, (2) institutional programs and policies to support learning, (3) a champion who provided focus and belief related an issue valued by the institution, and (4) a sage advisor who had a great deal of experience in the area where change was desired.

These four key elements worked together to draw more and more people into learning about and implementing the desired innovations (See Figure 10.1). Over time, leaders who desired to sustain the changes and help direct and scale-up the benefits saw the need to study and understand what happened. The most crucial of the drivers was the group of individual faculty members working together to learn and change. The institution provided them with essential capacity-building programs, a policy requiring all incoming 
faculty members to earn credentials in learning and teaching, and incentives to help them utilize development programs. Incentives included awards, fellowships, faculty enrichment grants, tuition-remission, and course-release time. The institution also provided time for an administrative sage (a head of learning development) and faculty champion (who was awarded a teaching fellowship) to organize activities. These individuals led what became a small movement that grew into a noteworthy transformation in teaching practices. Yet, as the model illustrates, neither the champion nor the sage could directly move the larger wheel of change. Instead, they affected change by engaging with others and leveraging institutional resources.

Individual Learning. Initial resistance to change shifted as more individuals adopted the desired learning behaviors and practices. Individual teachers learned a range of new skills and behaviors. Consistent with the behavioral change model by Prochaska and Diclemente (1984), some individuals were initially unaware that change was needed/merited. This can range from a simple lack of awareness to denial of a need to change and/or active resistance. When things began to challenge that initial perception, a person began to contemplate action, determine to act, and take action to change or learn a new behavior. If the person is well-supported, s/he may be able to take this farther: evaluating outcomes, refining behaviors, and maintaining the changes. Learning with a group can help; having an established place and time to reflect upon and discuss outcomes with others allows the learner to consider alternative approaches and hear about what worked in other contexts.

Organizational Learning. In optimal cases leaders help mobalize, implement, and institutionalize change (Kezar, 2009). Mobilization of new approaches, according to VanDerLinden (2014), involves "providing vision and harnessing enthusiasm" (p. \# TBD) whereas implementation requires putting proper process and structures in place. Thus, the final stage of most models of planning/learning deals with monitoring, evaluating, and stabalizing 
desired changes. Individual teachers and students must mointor, perfect, and maintain thier own teaching and learning practices. Organizations must provide resources to foster and sustain the new behaviors. Leaders must help channel activities so that energies flow in desired directions.

A Model to Promote Adoption. Below is a model (See Figure 10.2) that provides a way to conceptualize the process of learning and change. Leaders can use it to help encourage adoption of new techniques by a critical mass (e.g., the early and late majority that represent the bulk of any given population)

[ [ Insert Figure 10.2 About Here] ]

Typically, the champion serves as the innovator who leverages the work of early adopters of new pedagogical practices. The learning/development can be enhanced by institutional support (in the form of policies and programs) and engagement of a sage advisor who can highlight relevant theories and examples, as was the case at DIT. Over time, more join the process to create the early majority, with the addition of the late majority buying in as they see improved student outcomes and increased student demand.

Lowe (2012) says leaders of socially-driven enterprize should not waste precious resources trying to enlist lagards (who he defines as bystanders and naysayers). Rather, organizationas will benefit most from recruiting skeptics who typically fall at the center of this bell curve. Moreover, Lowe says, leaders can yield the highest return on investment by helping "ensure the people who are using the solution are leveraging it to the maximum" (II8) • Leaders should focus on helping constituents fully comprehend new approaches and learn to implement them effectively.

Leadership for Learning. As found in the DIT research, faculty learning can foster--and is indeed central to--organizational learning (Chance et al., 2013a, 2013b; Chance, Duffy, \& Bowe, under review). Any institution that 
wants to improve student learning will need faculty buy-in. Universities rely on faculty learning in order to achieve changes in teaching practices. The example of DIT reflects best practices noted elsewhere in this volume. There, change was framed as a scholarly act that resulted in the willing engagement of faculty (Moore \& Mendez, 2014). The models provided above helped map the institution's learning environment as recommended by Wawrzynsky and Baldwin (2014). Faculty members were engaged in critical reflection about how to achieve optimal learning (VanDerLinden, 2014). In keeping with suggestions by Moore and Mendez, the faculty in the learning group at DIT effectively modeled "reflective practice" about "how students at their institution engage and the outcomes of this engagement" (P. \# TBD). The work helped constituents become more conscious and purposeful in their learning. As a result of this reflection, practices that support learning become more "embedded in the systems, structures, routines, practices, and strategies" (VanDerLinden, 2014, p. \# TBD) of the institution and its various programs.

Consistent with Amey's (2014) recommendations, leaders in the organization helped construct a "learning infrastructure" of "support systems that foster people's willingness to take risks and learn" (p. \# TBD). The system effectively provided "the space for thinking, reflecting, trying on new ideas, transitions, internalizing new understandings and institutionalizing new processes" ( $p$. \# TBD). These factors helped build succes and expand the group of educators facilitating change.

\section{Summary}

Although many chapters in this volume focus on learning within specific stakeholder groups (i.e., student, or faculty, or administrative leaders), there are clear commonalities. The examples provided in this chapter highlight a number of ways learning can occur across various stakeholder 
groups. All these groups can benefit from iterative thinking and from being exposed to heuristic processes for planning, decision-making, and selfdirected learning (Chance, 2010). They all need to know how to set benchmarks for success, monitor and evaluate their actions, and tweak their performance/behaviors.

Disrupting their status quo, while providing appropriate levels of challenge and support can help them learn and grow (Sanford, 1962). Disruptive thinking is essential to spurring paradigm shifts (Kuhn, 1962) and to moving organizations from "good" to "great" (Collins \& Hansen, 2011). In fact, Christensen and associates (2011) argue that disruptive technologies will radically transform learning at all levels; this will help humanity develop knowledge much more effectively.

Using the models provided in this chapter can help institutional leaders leverage resources and prompt learning. They can implement capacity building programs, empower champions and sage advisors, and work to align efforts for maximum effect. In cases where faculty members are already driving change, administrative leaders can and must help guide the change by providing essential resources. To maximize benefits, effective leaders will help scale up and sustain desired change. When this is done well, it can lead the organization in entirely new directions and can help define the institution's own unique role in education (Rowley et al., 1997).

\section{References}

Amey, M. J. (2014). Constructing an overarching framework for learning Connecting the dots. In P. L. Eddy (Ed.), Connection learning across the institution. New Directions for Higher Education (pp. \#\#). San Francisco, CA: Jossey-Bass.

Astin, A. W. (1999, September/October). Student involvement: A developmental theory for higher education. Journal of College Student Development, $40(5)$.

Barber, J. P. (2014). Integration of learning model: How college students integrate learning. In P. L. Eddy (Ed.), Connection learning across the institution. New Directions for Higher Education (pp. \#\#). San Francisco, CA: Jossey-Bass.

Barrows, H. (1994). Practice Based Learning: problem based learning applied to medical education. Spingfield: Southern Illinois School of Medicine. 
Birnbaum, R. (1988). How colleges work: The cybernetics of academic organization and leadership. San Francisco: Jossey-Bass.

Bornstein, R. (2003). Legitimacy in the academic presidency: From entrance to exit. Westport, CT: Praeger.

Chance, S. M. (2010). Strategic by design: Iterative approaches to educational planning. Planning for Higher Education, 38(2), 40-54.

Chance, S. M., Duffy, G., \& Bowe, B. (under review). Using learning groups to transform engineering education: A phenomenological study of educators' experiences of change. In A. McKenna, T. Litzinger, \& J. Froyd (Eds.). Special Issue of the Journal of Engineering Education.

Chance, S. M., Duffy, G., Bowe, B., Murphy, M., \& Duggan, T. (2013a). A model for transforming engineering education through group learning. Proceedings of the International Conference on Engineering and Product Design Education. Dublin, Ireland.

Chance, S. M., Eddy, P. L., Duffy, G., Bowe, B., \& Harvey, J. (2013b). Policies that enhance learning and teaching. Proceedings of the World Academy of Science, Engineering and Technology; International Conference on Higher Education. Paris, France.

Chase, G. W., \& Rowland, P. (2005). The Ponderosa Project: Infusing sustainability in the curriculum. In P. F. Bartlett \& G. W. Chase (Eds.), Sustainability on campus: Stories and strategies for change (91-105). Cambridge, MA: MIT Press.

Chickering, A. W. \& Reisser, L. (1993). Education and identity. (2 nd ed.). San Francisco: John Wiley and Sons.

Christensen, C. M., Horn, M. B., \& Johnson, C. W. (2011). Disrupting class: How disruptive innovation will change the way the world learns. NY, NY: McGraw Hill.

Collins, J., \& Hansen, M. T. (2011). Great by choice: Uncertainty, chaos, and luck-Why some survive despite them all. NY, NY: HarperCollins.

Dudley, D. (2009, September 18). Oberlin buildings LEED the way: Environmentally conscious construction sweeps campus. The Oberlin Review. Retrieved October 18, 2009, from http://www.oberlin.edu/cgibin/cgiwrap/ocreview/20090918.php?a=n_leed\&sec=news

Duffy, G., \& Bowe, B. (2010a). A framework to develop lifelong learning and transferable skills in an engineering programme. Paper presented at the 3rd International Symposium for Engineering Education. University College Cork, Ireland.

Eddy, P. L. (2014). Faculty as border crossers: A study of Fulbright faculty. In P. L. Eddy (Ed.), Connection learning across the institution. New Directions for Higher Education (pp. \#\#). San Francisco, CA: Jossey-Bass.

Fullan, M. (2001). Leading in a culture of change. San Francisco: JosseyBass.

Holcomb, E. L. (2001). Asking the right questions ( $2^{\text {nd }}$ ed.). Thousand Oaks, CA: Corwin Press.

Kerr, C. (1995). The uses of the university (4 ${ }^{\text {th }}$ ed.). Cambridge, MA: Harvard University Press.

Kezar, A. (2005a). Understanding the learning organization in higher education. In A. Kezar (Ed), Higher education as a learning organization: Promising concepts and approaches. New Directions for Higher Education, (pp. 1-13). Number 131/Fall. San Francisco: JosseyBass.

Kezar, A. (2005b). What do we mean by "learning" in the context of higher education? In A. Kezar (Ed)., Higher education as a learning organization: Promising concepts and approaches. New Directions for Higher Education, (pp. 47-62). Number 131/Fall. San Francisco: JosseyBass. 
Kezar, A. (2009). Synthesis of scholarship on change in higher education. Paper presented at Mobilizing STEM Education for a sustainable Future, Emory University, Atlanta, GA.

Kolb, D. A. (1984). Experiential learning : experience as the source of learning and development. Englewood Cliffs; London: Prentice-Hall.

Kolb, D. A. (1998). Learning styles and disciplinary differences. In K. A. Feldman \& M. B. Paulsen (Eds.), Teaching and learning in the college classroom pp. 127-137. Needham Heights, MA: Simon \& Schuster.

Kuhn, T. (1962). The structure of scientific revolutions. Chicago, IL: University of Chicago.

Lauer, L. (2006). Advancing higher education in uncertain times. Washington, DC: Council for Advancement and Support of Education.

Leslie, D. (2014). "Orthogonality" in learning and assessment. In P. L. Eddy (Ed.), Connection learning across the institution. New Directions for Higher Education (pp. \#\#). San Francisco, CA: Jossey-Bass.

Lewis, T. L., \& Niesenbaum, R. A. (2005, June 3). The benefits of short-term study abroad. The Chronicle of Higher Education. Retrieved Sunday, November 05, 2006. (ERIC Document Reproduction Service No. EJ716524)

Lowe, G. (4 Jan. 2012). For Enterprise Social Networks: How much adoption is enough? http://blog.yammer.com/blog/2012/01/how-much-adoption.html

McDonough, W. \& Braungart, M. (2002). Cradle to cradle: Remaking the way we make things. New York: North Point.

Moore, T. M., \& Mendez, J. P. (2014). Civic engagement and organizational learning strategies for student success. In P. L. Eddy (Ed.), Connection learning across the institution. New Directions for Higher Education (pp. \#\#). San Francisco, CA: Jossey-Bass.

NAFSA: Association of International Educators. (2003, November). Securing America's future: Report of the strategic task force on education abroad. Washington D.C.: NAFSA: Association of International Educators. Downloaded on November 11, 2006. http://www.nafsa.org/_/Document/_/securing_america_s_future.pdf

NAFSA: Association of International Edücators. (2006, July 27). Legislation introduced to dramatically expand study abroad among American college students; Bill proposes visionary program to ensure Americans are internationally educated. NAFSA press release. Downloaded from U.S. Newswire on November 11, 2006. http://releases.usnewswire.com/GetRelease.asp?id=69879

Neumann, A., \& Bolitzer, L. (2014). Finding and fostering learning: What college and university leaders need to know and what they can do. In P. L. Eddy (Ed.), Connection learning across the institution. New Directions for Higher Education (pp. \#\#). San Francisco, CA: JosseyBass.

Oberlin College. (2007b). Media: Interviews. Retrieved November 1, 2009, from http://www.oberlin.edu/ajlc/media_4.html

Orr, D. W. (1999). Reassembling the pieces: Ecological design and the liberal arts. In G. A. Smith \& D. R. Williams (Eds.) Ecological education in action: On weaving education, culture, and the environment, 229-236. New York: State University of New York Press.

Orr, D. W. (2007). Ecological design and education. In J. Pretty, A. S. Ball, T. Benton, J. S. Guivant, D. R. Lee, D. Orr, M. J. Pfeffer, \& H. Ward (Eds.), The SAGE handbook of environment and society (209-223). Los Angeles: SAGE.

President and Fellows of Harvard College. (2009). Harvard receives 20th LEED certification. Retrieved September 29, 2009, from http://www.green.harvard.edu/node/461 
President and Fellows of Harvard College. (2010). Fine arts library receives LEED gold certification. Retrieved February 20, 2010, from http: / /www.hcl.harvard.edu/news/articles/2010/leed_certification.cfm

Presley, J. B., \& Leslie, D. W. (1999). Understanding strategy: An assessment of theory and practice. In J. C. Smart \& W. G. Tierney (Eds.), Higher education: Handbook of theory and research, 14 (201-239). Bronx, NY: Agathon Press.

Prochaska, J. O., \& DiClemente, C. C. (1984). The Transtheoretical Approach: Crossing traditional boundaries of therapy. Homewood, IL: Dow JonesIrwin.

Rowley, D. J., Lujan, H. D., \& Dolence, M. G. (1997). Strategic change in colleges and universities: Planning to survive and prosper. San Francisco: Jossey-Bass.

Sanford, N. (1962). The American college. New York, NY: Wiley.

Sharp, L. (2009). Higher education: The quest for the sustainable campus. Sustainability: Science, Practice, and Policy (5)1, p. 1-7.

VanDerLinden, K. (2014). Blended learning as transformational institutional learning. In P. L. Eddy (Ed.), Connection learning across the institution. New Directions for Higher Education (pp. \#\#). San Francisco, CA: Jossey-Bass.

Wawrzynski, M., \& Baldwin, R. (2014). Promoting high impact student learning: Connecting key components of the collegiate experience. In P. L. Eddy (Ed.), Connection learning across the institution. New Directions for Higher Education (pp. \#\#). San Francisco, CA: JosseyBass.

Wilson, D. (1997). Project monitoring: A newer component of the educational planning process. Educational Planning 11(1), 31-40.

Xiangyun, D., de Graaff, E. \& Kolmos, A. (Eds.). (2009). Research on PBL Practice in Engineering Education. Rotterdam: Sense Publishers.

Yadav, A., Subedi, D., Lundeberg, M. A., Bunting, C. F. (2011). Journal of Engineering Education,100(2), 253-280.

Zakrajsek, T. (2014). Developing learning in faculty. In P. L. Eddy (Ed.), Connection learning across the institution. New Directions for Higher Education (pp. \#\#). San Francisco, CA: Jossey-Bass. 
Figure 10.1: Model for Multi-Level Learning (Adapted from Chance, Duffy, \& Bowe, under review)

Individual Learning $\quad>\quad$ Group Learning $\quad>\quad$ Organizational Learning

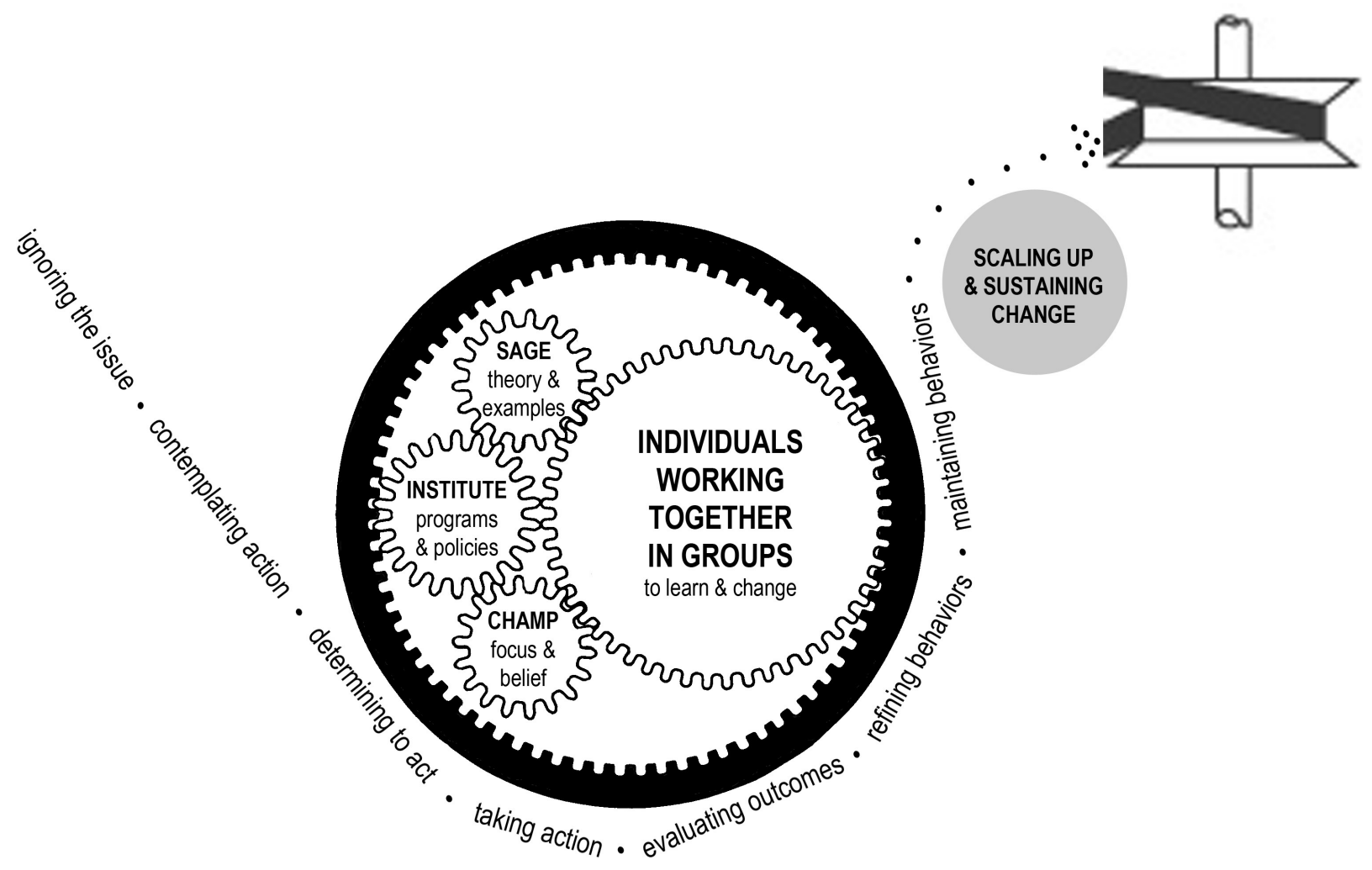

Figure 3: Factors driving adoption of learning/change (Source: Chance et al., 2013a).

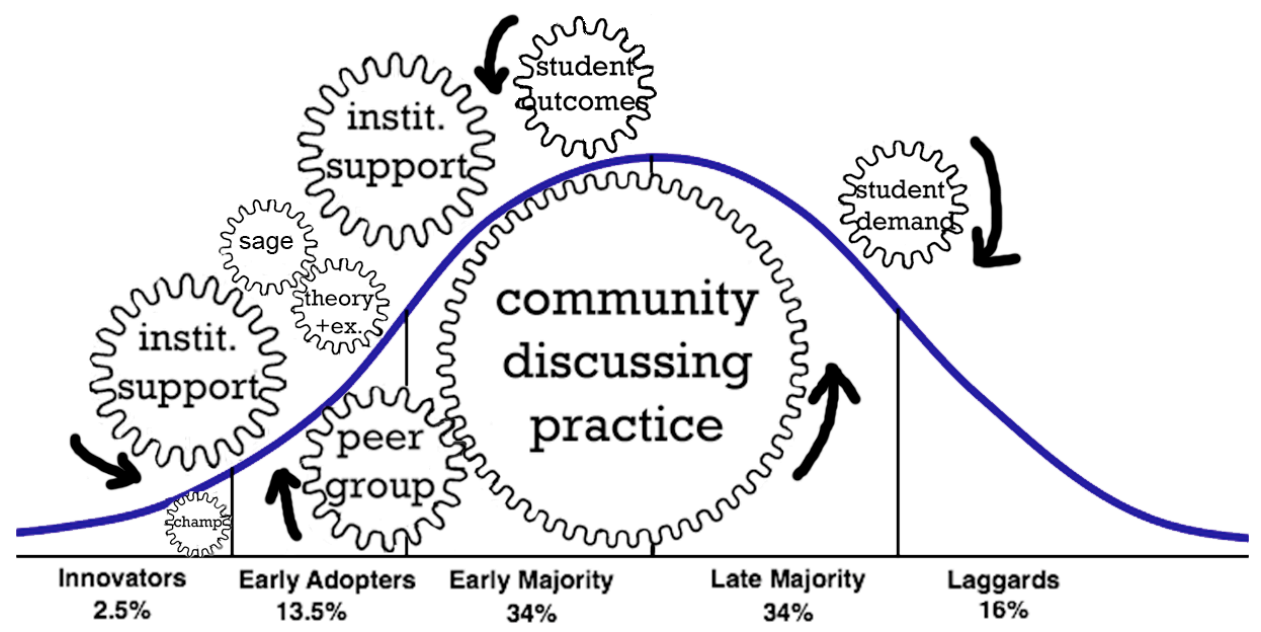

